\title{
Transport system of megalopolis and its influence on the urban environment (the example of St. Petersburg)
}

\author{
Tatiana Tereshkina ${ }^{1}$, Natalia Verstina ${ }^{2} *$, Marina Treyman $^{3}$ and Artyom Tereshkin ${ }^{4}$ \\ ${ }^{1}$ Saint Petersburg State University of Industrial Technologies and Design (SPbSUITD), 191186, 18, \\ Bolshaya Morskaya street, Saint-Petersburg, Russia \\ ${ }^{2}$ Moscow State University of Civil Engineering, Yaroslavskoe shosse, 26, Moscow, 129337, Russia \\ ${ }^{3}$ Saint Petersburg State University of Industrial Technologies and Design (SPbSUITD), 191186, 18 , \\ Bolshaya Morskaya street, Saint-Petersburg, Russia \\ ${ }^{4}$ Saint Petersburg State University of Industrial Technologies and Design (SPbSUITD), 191186, 18, \\ Bolshaya Morskaya street, Saint-Petersburg, Russia
}

\begin{abstract}
The transport system of one of the largest megalopolises in Russia is analysed in the article, the assessment of its transport potential is carried out and the main problems of the transport complex development, which need to be solved within the implementation of the concept of the "smart" city in St. Petersburg are revealed. The classification of the environmental impacts of functioning of the city transport system is given and the characteristic of the most significant ecologic-and-economic problems of St. Petersburg, connected with the use of the motor transport, having a special impact on the urban economic environment is given. Technique for the assessment of the impact of motor transport on the environment of the megalopolis is offered by the authors and the calculation of the Green Avto Index, characterizing the ecological situation in the districts of Saint-Petersburg, which needs to be considered when planning the urban development and the organization of traffic flows are carried out. The international experience of the application of the "intellectual" transport systems, which use will allow to accelerate the process of the creation of the platform for transition to the "smart" city in the megalopolis is considered.
\end{abstract}

\section{Introduction}

The city transport system is the integral component of the "smart" city and forms its further perspective development in the social, ecological and economic aspects. The main objective of the "smart" cities is the implementation of new technologies in all the spheres of human

\footnotetext{
Corresponding author: verstina@mail.ru
} 
life in order to make functioning of the city infrastructure more efficient, and also to make the citizens' life comfortable and safe $[1,2]$.

The issues of the transport infrastructure development are rather acute in the modern reality and their solution is necessary for the effective functional development of any large city in all the countries of the modern world. The transport sector is presented by various means of transport which have to apply innovative technologies for their further effective development and to introduce some advanced methods, allowing the transport systems to become economic, eco-friendly, socially available, to assure safety and quality of transportations of both freights, and passengers. Transition to the "intellectual" and "smart" transport systems, allowing to automate and dispatch the transport processes [3] has to become the final result of the development of transport in megalopolises.

That is obvious, that the system of infrastructure of megalopolises will systematically develop in the estimated prospect, therefore the state needs to invest considerable investments into construction of the transport systems, their reconstruction and to consider their needs for further development.

The common transport problems are characteristic of the Russian megalopolises. The same problems are familiar to the countries of the former Soviet Union including Uzbekistan.

Experts in the field of transport of Uzbekistan note the existence of high potential of the development of the transport infrastructure of the large cities, which dynamics still remains poor. "Concept of the development of the city passenger transport of Tashkent until 2030", was discussed at the level of Government, which principles and directions of the transport development are in the context of the world trends. Similar problems are also being solved in the Russian megalopolises; in this regard, according to the authors, the important matter is the analysis of the accumulated experience and formation of some scientifically reasonable provisions on the implementation of the "smart" city ideology, regarding the transport infrastructure.

\section{Materials and Methods}

St. Petersburg is one of the largest megalopolises and transport hubs of Russia, holding the second place after Moscow. The transport complex of St. Petersburg is presented by all the means of transport: automobile, railway, water (including sea and river), air (military and civil aviation) and pipeline as well. The transport system of the city is characterized by the following indexes [3, 4]: at the total area of the urban area of 1.439 sq.km, the extent of street and road highways is $3.711 \mathrm{~km}$, i.e. the average density of networks of highways is $2.6 \mathrm{~km}$ per 1 sq. km. $86 \%$ in the structure of the network are the communication facilities, which are buildings, while roads make up $14 \%$ [5].

The city has the significant quantity of transport hubs: 121 main hubs and 88 minor hubs. Such number of transport hubs demonstrates that the city extends, but at the same time, traffic jams are still formed.

The transport system of the city underwent the significant changes: the ring highway (ring road) and the Western High-Speed Diameter (WHSD), seaport and air terminal were built and other logistics systems of the city infrastructure are reconstructed.

The transport network of the city is rather developed, but it is not systematized as it is required for the orientation to creation of the "smart" city; that causes the considerable problems in the creation of rational infrastructure and negatively influences the social-andecological conditions in the megalopolis.

The classification of environmental impacts of functioning of the city transport system, used in the research is presented in Figure 1. 


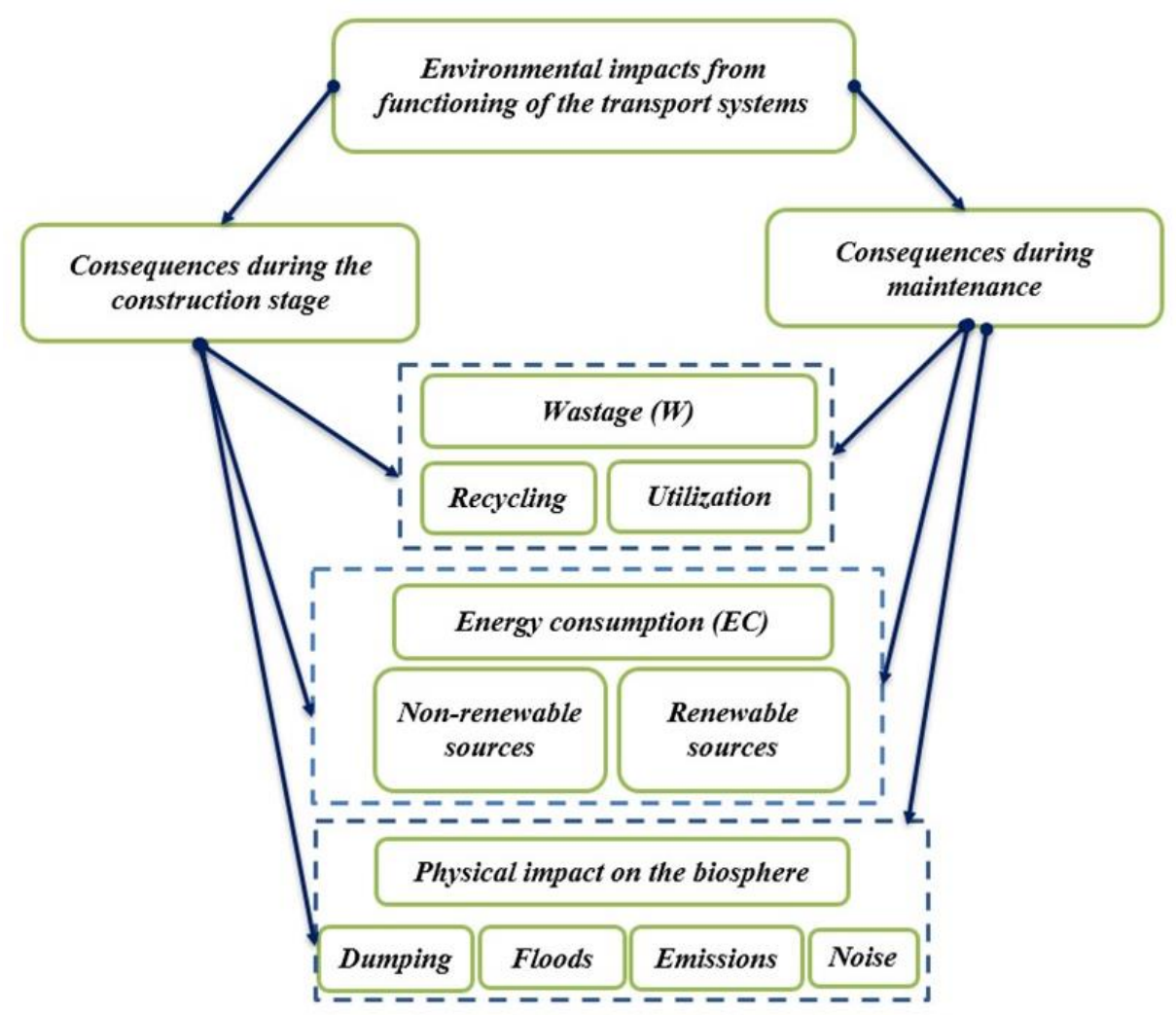

Fig. 1. Classification of environmental impacts of functioning of the transport system [6]

Taking into account the theory of sustainable development the effectiveness of transport in the megalopolis, focused on the creation of the "smart" city, is estimated depending on the vectors of three essential factors as follows:

$$
\mathrm{E}=\mathrm{f}(\mathrm{C}, \mathrm{T}, \grave{\varepsilon})
$$

\section{(1)}

where :

E - effectiveness of transport;

$\mathrm{C}$ - vector of economic processes;

$\mathrm{T}-$ vector of social factors;

$\grave{\varepsilon}-$ vector of ecological processes.

Thus, in the context of the theory of sustainable development which, according to authors, has to enter the structure of the theoretical basis of the "smart" city ideology, it is possible to define effectiveness of transport of the megalopolis taking into account the vectors given above (Table 1).

Table 1. Calculation of transport effectiveness according to the theory of sustainable development

\begin{tabular}{|c|l|c|}
\hline \multicolumn{2}{|c|}{ Transport effectiveness, E } \\
\hline Economic & \multicolumn{1}{|c|}{ Social } & Mcological \\
\hline Price availability of transport & \multicolumn{1}{c|}{ Mobility } & Environmental safety \\
\hline $\begin{array}{c}\text { Analysis of dynamics of the } \\
\text { transport services cost in the } \\
\text { interrelation with change of } \\
\text { inhabitants' income }\end{array}$ & $\begin{array}{l}\text { Analysis of time for movement } \\
\text { of the inhabitants about the city, } \\
\text { on their way to work, losses of } \\
\text { time at idle time in the traffic } \\
\text { jams }\end{array}$ & $\begin{array}{c}\text { Assessment of the } \\
\text { impact of all the means } \\
\text { of transport on the } \\
\text { environment and on the } \\
\text { inhabitants' health }\end{array}$ \\
\hline
\end{tabular}


The main problems of the transport complex of St. Petersburg, which need to be solved in the megalopolis within the transition to the "smart" city are the following [7, 8]:

- rather low reliability of movement in the city roads network, happening because of traffic jams (in rush hours traveling speed makes no more than $5-10 \mathrm{~km} / \mathrm{h}$ because of traffic jams) and the lack of the alternate routes and overload of transport arteries;

- poor quality of the street space and road networks in the city;

- considerable overload of the city space with the automobile transport;

- development of the city infrastructure seriously lags behind the sharply changing conditions of the environment in the city and needs of the state and society;

- unfavourable transition to the new social-and-economic model of the development of the population and the city development.

During the analysis of the current "Complex transport scheme of St. Petersburg" some"problem zones", existing immediately in the road network of the megalopolis were revealed [8]:

- low channel capacity of individual transport;

- the considerable problems in the public transport service. For example, share taxis often occupy the sites, intended for public transport and break driving;

- the insufficient channel capacity of pedestrians - the city infrastructure does not consider the problem of passenger traffics movements.

Permission of transport problems of the megalopolis is promoted, first of all, by development of public transport and also the creation of necessary quantity of terminals for turnpike means of transport. As the international experience proves, the insufficient operational work of the public transport structures reduces the mobility of the population and prevents to develop some transport sites. Thus, the transport system of the megalopolis demands the considerable modernization, implementation of the principles of multimodal transportations in practice as well as new approaches, including ecological one $[9,10]$.

The analysis, carried out by the authors, proved, that the problems, preventing the development of the motor transport in the city and highways are the following:

1. There is no rather mobile and operational terminal for long-distance bus routes.

2. The considerable loading of the ring highway causes the necessity of construction both additional paths and outcomes, and constructions of the new ring road.

3. There is no unity for cargo highways and there is no synchronization of freght traffic.

4. Formation of transport traffic jams and jams on entrances to the city that demands expensive reconstruction of highways [10].

The significant amount of problems is connected with other means of transport: water, air and railway, which also develop in St. Petersburg actively, but they are not considered in this article.

Only motor city transport is analyzed, as it has special influence on the urban economic environment, being the dinamic element of the processes of transition to "the smart city", having significant effect on rationality of location of places of work application, exchange of resources and products of work, as well as on the production efficiency in general [11, $12]$.

In St. Petersburg with its population of 5.2 million inhabitants the vehicle fleet makes up 1665.3 thousand cars (319 automobile vehicles per one thousand motorists). Average age of the vehicle fleet is 12.5 years.

The park of trucks contains about 214 thousand pieces. The average age is 20 years, and two thirds of the cars are elder than 15 years [13].

The specific place in the transport system of any city is held by public transport.

In St. Petersburg public transport is presented by trams, buses and trolleybuses as land transport, and subway cars as underground transport. 
The quantity of units of public transport of the megalopolis as well as volumes of transport work are presented in Table 2 [14].

Table 2. Public transport of St. Petersburg

\begin{tabular}{|l|c|c|}
\hline Name of equipment & $\begin{array}{c}\text { Quantity of equipment, } \\
\text { pieces }\end{array}$ & $\begin{array}{c}\text { Volume of transport } \\
\text { work, thousand } \mathbf{~ k m}\end{array}$ \\
\hline Subway cars & 1711 & 213080 \\
\hline Tram cars & 789 & 34362 \\
\hline Trolleybuses & 634 & 28679 \\
\hline Buses & 2591 & 159604 \\
\hline
\end{tabular}

In 2017 there were 336 city highways including 2134 sections in the city. The circle road $142.15 \mathrm{~km}$ long is located around the city.

In St. Petersburg the Russia's first paid intracity highway for high-speed driving (Western High-Speed Diameter) is located. According to the report "Western High-Speed Diameter. The nontechnical summary" this highway has the following technical parameters [15]:

- Total length - $46.6 \mathrm{~km}$;

- Length on artificial constructions $-26.7 \mathrm{~km}$

- Quantity of traffic intersections - $9(+4)$;

- Quantity of strips: 4-8;

- Maximum allowed traveling speed $-110 \mathrm{~km} / \mathrm{h}$;

- Average intensity of driving - more than 100 thousand cars a day.

The Western High-Speed Diameter solves the most important federal problem of the transport service of the Seaport of St. Petersburg. The construction of the Western HighSpeed Diameter also provides motor transportation availability of a passenger ferry complex in alluvial territories of Vasilyevsky Island, allows to unload the centre of the city and, as a result, to achieve the decrease in emissions by $14 \%$.

The operation of motor transport is connected with the selection of a huge amount of pollutants in the air that during the transition to the "smart" city, it becomes a problematic issue of the transport infrastructure.

Cars are known to use fuel, containing great amount of oil products, which emit exhaust gases during combustion. In total more than 200 chemicals are revealed as a part of combustion gases. Emissions of harmful substances from the motor transport are the following: white damp (SO), volatile organic compounds, nitrogen oxides, carbon dioxide (CO2), suspended matters. These substances, emitted by engines of cars accumulate in free air in a great many, especially near large highways [16].

Except combustion gases the solids, which are formed at sharp braking, of the car get to free air. In case of sharp braking the greatest negative impact on free air goes not from the gases emitted at fuel combustion, but because of interaction of the road and wheels of cars. During such braking the car leaves a mark from tires. At this moment a sliding friction between the paving and tires of the car is so great, that leads to an attrition of shoes, clutch plates of cars, rubber wear and wear of the road surface as well. All this is followed by emission of shallow particles of rubber and metals as well as asphalt particles in the area. This fine dust remains in the air over the loaded roads ingreat quantities. This process of an attrition is also the reason of the poor quality of the paving which constantly collapses because of larger thermal gradients. In case of attrition of brake blocks copper, vanadium, molybdenum, nickel, chrome get to air, cadmium, lead, zincum get to area because of the tires wear.

The greatest number of pollutants is thrown out at the acceleration of the car, as at this moment the engine consumes the greatest quantity of fuel, so emissions of combustion gases are most intensive then. 
The relative share of hydrocarbons and white damp from the lump of emissions is highest when braking and idling, the share of nitrogen oxides - during the acceleration of the car.

The quantity of emissions during driving and service of cars is distributed as follows: driving of cars - $66.57 \ldots 68.91 \%$; checkup and car repairs - $17.87 \ldots 20.4 \%$; production of fuel $-11.02 \ldots 11.41 \%$; production of materials for the checkup and repair $-1.8 \ldots 2.06 \%$. [17].

Specific emissions of pollutants for various groups of motor transport per $1 \mathrm{~km}$ of driving are presented in Table 3.

Table 3. Quantitative structure of emissions from motor transport

\begin{tabular}{|l|c|c|c|c|c|c|c|}
\hline \multirow{2}{*}{$\begin{array}{l}\text { Group of motor } \\
\text { transport }\end{array}$} & \multicolumn{7}{|c|}{ Emissions, g/km } \\
\cline { 2 - 8 } & $\mathrm{O}$ & $\mathrm{NO}_{2}$ & $\mathrm{CH}$ & $\mathrm{Soot}$ & $\mathrm{SO}_{2}$ & Formaldehyde & Benzopyrene \\
\hline Automobile & 3.5 & 0.9 & 0.8 & $0.7 * 10^{-2}$ & $1.5 * 10^{-2}$ & $3.2^{*} 10^{-3}$ & $0.3 * 10^{-6}$ \\
\hline $\begin{array}{l}\text { Motor vans and } \\
\text { minibuses }\end{array}$ & 8.4 & 2.1 & 2.4 & $3.8 * 10^{-2}$ & $2.8 * 10^{-2}$ & $8.4 * 10^{-3}$ & $0.8 * 10^{-6}$ \\
\hline $\begin{array}{l}\text { Cargo, from 3.5 } \\
\text { to 12 t }\end{array}$ & 6.8 & 6.9 & 5.2 & 0.4 & $5.1 * 10^{-2}$ & $2.2^{*} 10^{-2}$ & $2.1 * 10^{-6}$ \\
\hline Cargo, over 12 $\mathrm{t}$ & 7.3 & 8.5 & 6.5 & 0.5 & $7.3 * 10^{-2}$ & $2.5^{*} 10^{-2}$ & $2.6^{*} 10^{-6}$ \\
\hline $\begin{array}{l}\text { Buses, over 3.5 } \\
\mathrm{t}\end{array}$ & 5.2 & 6.1 & 4.5 & 0.3 & $4.2 * 10^{-2}$ & $1.8^{*} 10^{-2}$ & $1.8 * 10^{-6}$ \\
\hline
\end{tabular}

It is visible from the table, that cars and minibuses emit the greatest concentration of atomic oxygen in the atmosphere of the megalopolis, and trucks emit more nitrogen dioxide. The least selections of soot are observed for trucks with the loading capacity over 12 t. Motor transport contribution to air pollution of the city makes nearly $85 \%$ [18]. Emissions of nitrogen oxide and sulfur, provoking such diseases as asthma and allergic reactions have the most significant effectfor the health of the population. Atomic oxygen makes the significant contribution to global warming and destruction of the ozone layer of our planet.

Besides harmful emissions, it should be noted that motor transport contribution to the air pollution of megalopolises: this type of influence leads to nervous and physical diseases, decrease in hearing, decline in work productivity, high fatigue [19].

According to the experts, about $30 \%$ of inhabited facilities of the Northern Capital are located in the zones with the raised background noise. These are the houses which are in close proximity to large city highways, the acoustic background noise on them exceeds the norm almost 10 times. In total in St. Petersburg $40 \%$ of automobile highways have the raised acoustic background noise.

Thus, the materials presented by authors prove, that even one of megalopolis means of transport is very problematic nowadays: the motor transport makes the significant contribution to the pollution of air regarding emissions of harmful gases, such as oxides of sulfur and nitrogen oxides. The noise pollution from motor transport, also influences not only on ecological, but also on social conditions and on the health of residents of the megalopolis essentially. Cars also occupy the significant areas (parkings, some inhabitants put cars near houses) and contribute significantly to mass pollution of the territory.

\section{Results}

The analysis of aforesaid materials demanded the introduction of estimated indicators for the formation of scientific reasonable provisions on the implementation of the "smart" city ideology regarding transport infrastructure. Green Avto Index was offered by the authors 
for the assessment of the impact of motor transport on the environmental environment of districts of the megalopolis. Calculation of the index is performed according to the formula:

$$
\text { Green Avto Index }=\sum \mathrm{P}_{1}+\mathrm{P}_{2}+\mathrm{P}_{3}+\ldots .+\mathrm{Pi} \text {, }
$$

where Pi - scoring criteria.

The main factors, influencing the value of the offered index are the following:

- traveling speed of motor transport;

- volume of emissions in the district;

- load of street network with transport;

- natural characteristics of the district.

Each factor has several criteria, depending on which this factor received its score.

Criteria and score for calculation of Green Avto Index for the districts of St. Petersburg are presented in Tables 4...7. Great volume of statistical and cartographic information on the districts of St. Petersburg during 2015 - 2018 was used for the quantitative assessment of criteria and ranging of the estimated indicators.

Table 4. Traveling speed of the motor transport

\begin{tabular}{|c|c|c|}
\hline Speed & Total percentage of toxic substances emissions & Score \\
\hline Idling & 7,3 & 1 \\
\hline Acceleration & 3,1 & 0,4 \\
\hline Constant speed & 2,9 & 0,2 \\
\hline Braking & 4,0 & 0,5 \\
\hline
\end{tabular}

Table 5. Volume of emissions of pollutants in the district

\begin{tabular}{|c|c|c|}
\hline Districts of St. Petersburg & Volume of emission, t/g*km & Score \\
\hline Admiralteysky & $<100$ & 0.25 \\
\hline Vasileostrovsky & $<100$ & 0.25 \\
\hline Vyborgsky & $<100$ & 0.25 \\
\hline Kalininsky & 100 & 0.5 \\
\hline Kirovsky & $100 \ldots 300$ & 0.7 \\
\hline Kolpinsky & $<100$ & 0.25 \\
\hline Krasnogvardeysky & 100 & 0.5 \\
\hline Krasnoselsky & $<100$ & 0.25 \\
\hline Kronstadtsky & $<100$ & 0.25 \\
\hline Kurortny & $<100$ & 0.25 \\
\hline Moscovsky & $<100$ & 0.25 \\
\hline Nevsky & 100 & 0.5 \\
\hline Petrogradsky & $<100$ & 0.25 \\
\hline Primosky & $100 \ldots 300$ & 0.7 \\
\hline Petrodvortsovy & $<100$ & 0.25 \\
\hline Pushkinsky & $<100$ & 0.25 \\
\hline Frunzensky & 100 & 0.5 \\
\hline Centralny & $>300$ & 1 \\
\hline * the volume of emission is accepted according to the cartographic information & Schematic \\
map of emissions of motor transport in St. Petersburg & \\
\hline \multicolumn{2}{|c}{}
\end{tabular}

Table 6. Load of the street network with transport

\begin{tabular}{|c|c|c|}
\hline Districts of St. Petersburg & Load of the street network, points & Score \\
\hline Admiralteysky & 4 & 0.4 \\
\hline Vasileostrovsky & 3 & 0.3 \\
\hline Vyborgsky & 3 & 0.3 \\
\hline Kalininsky & 5 & 0.5 \\
\hline
\end{tabular}




\begin{tabular}{|c|c|c|}
\hline Kirovsky & 6 & 0.6 \\
\hline Kolpinsky & 2 & 0.2 \\
\hline Krasnogvardeysky & 3 & 0.3 \\
\hline Krasnoselsky & 3 & 0.3 \\
\hline Kronstadtsky & 4 & 0.4 \\
\hline Kurortny & 3 & 0.3 \\
\hline Moscovsky & 4 & 0.4 \\
\hline Nevsky & 4 & 0.4 \\
\hline Petrogradsky & 7 & 0.7 \\
\hline Primosky & 3 & 0.3 \\
\hline Petrodvortsovy & 3 & 0.3 \\
\hline Pushkinsky & 3 & 0.3 \\
\hline Frunzensky & 4 & 0.4 \\
\hline Centralny & 7 & 0.7 \\
\hline
\end{tabular}

Table 7. Natural characteristics of the district

\begin{tabular}{|l|l|}
\hline \multicolumn{1}{|c|}{ Criterion } & \multicolumn{1}{c|}{ Range of scores } \\
\hline $\begin{array}{l}\text { Gas contamination of the } \\
\text { territory }\end{array}$ & $\begin{array}{l}0.1 \text { - low level; } \\
1 \text { - high level. }\end{array}$ \\
\hline Existence of vegetation & $\begin{array}{l}0.1 \text { - large number of green territories; } \\
1-\text { there are no parks in the territory (industrial zone). }\end{array}$ \\
\hline $\begin{array}{l}\text { Territories occupied by } \\
\text { roads }\end{array}$ & $\begin{array}{l}0.1 \text { - there are no large highways; } \\
1 \text { - existence of large highways, the proximity with the circle } \\
\text { road, Western High-Speed Diameter. }\end{array}$ \\
\hline Quantity of motor transport & $\begin{array}{l}0.1 \text { - each 10 people have a car; } \\
1 \text { - each person has a car. }\end{array}$ \\
\hline Population density & 0.1 - less than 100 thousand inhabitants; \\
& 1 - more than 500 thousand inhabitants. \\
\hline Existence of parkings & 0.1 - there are no large parkings, only domestic; \\
& 1 - existence of large multystoried parkings. \\
\hline $\begin{array}{l}\text { Existence of large facilities } \\
\text { of social structure }\end{array}$ & $\begin{array}{l}0.1 \text { - there are no industrial facilities (dormitory area); } \\
1-\text { mainly industrial zone. }\end{array}$ \\
\hline
\end{tabular}

Thus, if index value is close to 10 , the district of the megalopolis is characterized as the "ecological disaster", and if its value is equal to 1 and less, it is characterized as a favorable ecological situation.

The calculation results of Green Avto Index for the districts of St. Petersburg are presented in Table 8.

Table 8. Green Avto Index value for the districts of St. Petersburg

\begin{tabular}{|c|c|l|}
\hline $\begin{array}{c}\text { Districts of St. } \\
\text { Petersburg }\end{array}$ & Index value & \multicolumn{1}{c|}{ Characteristic } \\
\hline Admiralteysky & 7 & $\begin{array}{l}\text { Industrial district, characterized by adverse ecological } \\
\text { conditions. }\end{array}$ \\
\hline Vasileostrovsky & 7 & $\begin{array}{l}\text { District, located in adverse ecological conditions. } \\
\text { Soils and air are strongly polluted. }\end{array}$ \\
\hline Vyborgsky & 2 & Favorable ecological situation. \\
\hline Kalininsky & 4 & $\begin{array}{l}\text { Residential quarters have more favorable } \\
\text { arrangement, indexes of the ecosystem do not exceed } \\
\text { the permissible values. }\end{array}$ \\
\hline Kirovsky & 5 & $\begin{array}{l}\text { Increased indicators of gas contamination are } \\
\text { observed near the metro station. "Prospect } \\
\text { Veteranov" and "Avtovo". At the same time, the } \\
\text { radiation level is normal, the greening of the district }\end{array}$ \\
\hline
\end{tabular}




\begin{tabular}{|c|c|c|}
\hline $\begin{array}{l}\text { Districts of St. } \\
\text { Petersburg }\end{array}$ & Index value & Characteristic \\
\hline & & makes up 30-40\%. \\
\hline Kolpinsky & 2 & $\begin{array}{l}\text { Pollution-free, the condition of soils and air as well as } \\
\text { radiation background do not extend norm }\end{array}$ \\
\hline Krasnogvardeysky & 8 & $\begin{array}{l}\text { District, located in the adverse ecological conditions, } \\
\text { because of a great quantity of the industrial plants and } \\
\text { enterprises. }\end{array}$ \\
\hline Krasnoselsky & 2 & Favorable ecological situation. \\
\hline Kronstadtsky & 2 & Favorable ecological situation. \\
\hline Kurortny & 2 & Favorable ecological situation. \\
\hline Moscovsky & 5 & $\begin{array}{l}\text { Uneven environmental performance. Residential } \\
\text { quarters are in rather safe area, but soils have the } \\
\text { significant differences in the extent of pollution. The } \\
\text { most adverse ecological state is noted in the north. }\end{array}$ \\
\hline Nevsky & 7 & $\begin{array}{l}\text { One of adverse districts of the city. It is caused by the } \\
\text { industrial enterprises and automobile highways } \\
\text { located there. }\end{array}$ \\
\hline Petrogradsky & 5 & $\begin{array}{l}\text { Satisfactory condition of the ecological situation, the } \\
\text { area of green plantings reaches } 35 \% \text {. Insignificant } \\
\text { aberrations of impurity of air and soils are noted on } \\
\text { Petrogradskaya Embankment. }\end{array}$ \\
\hline Primosky & 4 & $\begin{array}{l}\text { Residential quarters have the favorable arrangement, } \\
\text { indexes of the ecosystem do not exceed permissible } \\
\text { values. }\end{array}$ \\
\hline Petrodvortsovy & 2 & Favorable ecological situation. \\
\hline Pushkinsky & 2 & Favorable ecological situation. \\
\hline Frunzensky & 5 & $\begin{array}{l}\text { Non-uniform according to the degree of } \\
\text { environmental pollution. The ecology suffers from } \\
\text { the railway station "Kupchino", where the } \\
\text { considerable excess of lead, cobalt, chrome and } \\
\text { nickel is noted. Considerable loss of ecology of } \\
\text { Frunzensky district is caused by heat supplying plant } \\
\text { "Yuzhnaya". Green plantings make up } 40 \% \text {, radiation } \\
\text { is normal. }\end{array}$ \\
\hline Centralny & 7 & $\begin{array}{l}\text { One of the adverse districts of the city. That is caused } \\
\text { by the automobile highways, located there and great } \\
\text { quantity of motor transport, daily passing through the } \\
\text { district as a great stream. }\end{array}$ \\
\hline
\end{tabular}

The offered method of calculation of Green Avto Index will allow to carry out the complex assessment of the ecological situation in the districts of Saint-Petersburg, to analyze trends of its change and to consider when planning urban building, organization of traffic flows and development of the regulating measures. It is necessary to develop a complex of measures, which will allow to unload the transport stream and, thereby, to reduce emission of pollutants of for districts with high value of the index [18]:

- gardening of highways;

- the use of underground space for placement of parkings;

- removal of obstacles on the way of the free stream of cars (circle roads, inretsections, platforms and tunnels for unloading of a lane) [19, 20];

- transfer of public transport to the electric transport.

Thus, in general the situation in the city regarding gas contamination of the territory can be considered adverse and it is necessary to develop the effective measures for the improvement of environmental safety, including implementation of environmentally friendly technologies on transport, 
reversible logistics, and also the introduction of ecologically safe methods in the sphere of management of motor transport streams [21, 22].

Table 9. Most significant directions on the optimization of motor transport work in the direction of transition to the "smart" city format in the megalopolis [23, 24, 25]

\begin{tabular}{|l|l|}
\hline \multicolumn{1}{|c|}{ Name } & \multicolumn{1}{c|}{ Essence of the methods } \\
\hline Reversible logistics & $\begin{array}{l}\text { Re-using and processing of materials (packing materials, used } \\
\text { goods, industrial and consumption waste). }\end{array}$ \\
\hline $\begin{array}{l}\text { Use of the alternate } \\
\text { types of fuel for } \\
\text { vehicles }\end{array}$ & $\begin{array}{l}\text { Use of electric motors, gas fuel (hydrogenium, methanol), biosolar } \\
\text { oil, biofuel from solid organic waste, engines on liquid nitrogen, } \\
\text { etc. }\end{array}$ \\
\hline $\begin{array}{l}\text { Routing of logistic } \\
\text { streams }\end{array}$ & $\begin{array}{l}\text { Accurate scheduling of routes of transportation of goods, } \\
\text { completing of client orders; that leads to the reduction of volume of } \\
\text { transportations and also to the change of routes. }\end{array}$ \\
\hline Modified fuel & Change of fuel composition and the use of additives. \\
\hline $\begin{array}{l}\text { Technical and } \\
\text { constructive measures } \\
\text { concerning engines and } \\
\text { transport in general }\end{array}$ & $\begin{array}{l}\text { Use of innovative designs of engines, for example, diesel engines } \\
\text { with an undivided combustor, converting of diesel engines into gas } \\
\text { engines. }\end{array}$ \\
\hline
\end{tabular}

\section{Discussion}

One of the decisions in the current circumstances of the transition to the format of the "smart" city in the megalopolis is the application of the "smart" and "intellectual" transport systems in the urban environment The intellectual transport system is the system, allowing to collect and systematize information at a specific point in time under the given external conditions; that allows to realize functions of high complexity on processing of the considerable arrays of information and acceptance of the proper decisions regarding the transport systems management $[26,27,28]$.

The transport system of the city underwent the significant changes: the ring highway (ring road) and the Western High-Speed Diameter (WHSD), seaport and air terminal were built and other logistics systems of the city infrastructure are reconstructed.

The active interaction of the components "human-transport-environment" is provided by the complex Smart road system, which reflects when parameters which correspond to internal and external conditions are set in the modes of automation interaction [27]. The elements of innovations and components of the intellectual transport system of the megalopolis which are in the context of "the smart city" ideology are the following [29, 30]:

1. Intellectual control of traffic lights which allows to reduce the formation of traffic jams.

2. The use of clever materials for the road marking (the use of the LED paint and paint changing the drawing in case of the temperature change (emergence of frost) and that considerably increases safety).

3. Road blocking by special plates - solar batteries (the project has been implemented in the USA); that in the long term will allow to refuse of the electric delivery of the road external elements. Besides providing the road, energy can be also used for the delivery of networks of the Internet, television, communication, electrical networks.

4. Extraction of energy of moving transport (vehicles themselves emit kinetic energy during the contact with roughness of the road, this energy is perhaps useful for using a car, considerably reducing costs of gasoline).

Classification of the main criteria, which make possible to estimate, how successfully the processes of advance of the megalopolis in the direction of transition to the "smart" city are being carried out, is offered and presented in Table 10. 
Table 10. Classification of the main criteria of the "clever" transport system development [31]

\begin{tabular}{|l|l|}
\hline \multicolumn{1}{|c|}{ Contents } & \multicolumn{1}{c|}{ Characteristic } \\
\hline Condition of paving & $\begin{array}{l}\text { Coverings have to have the following properties: to operate } \\
\text { temperature mode, the paving condition, the anti-ice mode, etc. }\end{array}$ \\
\hline $\begin{array}{l}\text { Use of GIS- } \\
\text { technologies }\end{array}$ & $\begin{array}{l}\text { Automatic transport control mode } \\
\text { Creation of the system of monitoring and regulation of the key } \\
\text { parameters of traffic flows } \\
\text { Automation of traffic lights operation, etc. }\end{array}$ \\
\hline $\begin{array}{l}\text { Creation of certain } \\
\text { conditions on the } \\
\text { roadbed }\end{array}$ & $\begin{array}{l}\text { Need of creation of parameters of the road depending on weather } \\
\text { conditions, features of each season, state of environment. }\end{array}$ \\
\hline Ecological features & Reduction of emissions of harmful gases in the air. \\
\hline $\begin{array}{l}\text { Economy of the } \\
\text { resource component }\end{array}$ & $\begin{array}{l}\text { - fuel, materials for construction and maintaining of roads; } \\
\text { - time spent on repair and movement of transport; } \\
\text { - energy saving and resource efficiency. }\end{array}$ \\
\hline $\begin{array}{l}\text { Utilization of other } \\
\text { types of energy }\end{array}$ & $\begin{array}{l}\text { Solar energy, thermal transport energy and energy of air, mechanical } \\
\text { energy of moving transport. }\end{array}$ \\
\hline
\end{tabular}

During studying of the perspective of "the smart city" regarding perfecting of the transport infrastructure of the megalopolis, the most significant trends of use of "clever" transport which are classified and presented in Table 11 were created.

Table 11. Main trends in the field of management of "clever" transport [32]

\begin{tabular}{|l|l|}
\hline \multicolumn{1}{|c|}{ Trends } & \multicolumn{1}{|c|}{ Characteristics } \\
\hline $\begin{array}{l}\text { Infrastructure of transport } \\
\text { becomes intellectual }\end{array}$ & $\begin{array}{l}\text { Now cars themselve are the subject and the source of } \\
\text { information: they have sensors, tracking cameras, GPS, data } \\
\text { from these systems are collected and analyzed, making the basis } \\
\text { for monitoring the road condition. }\end{array}$ \\
\hline $\begin{array}{l}\text { Increase in transport } \\
\text { effectiveness due to } \\
\text { collateral operation }\end{array}$ & $\begin{array}{l}\text { Now for increase in the passenger traffic the following types of } \\
\text { applications can be used: } \\
- \text { car-sharing (car rental clockwise); } \\
- \text { cycling (development of infrastructure of bicycle transport and } \\
\text { roads for it); } \\
\text { - transportation by inquiries, taxi call via Uber. }\end{array}$ \\
\hline $\begin{array}{l}\text { Decrease in the ecological } \\
\text { influence on the transport } \\
\text { environment }\end{array}$ & $\begin{array}{l}\text { Use of "eco-friendly" brands of cars due to the application of the } \\
\text { alternative energy sources, the upgraded cars significantly } \\
\text { reducing load of the environment. }\end{array}$ \\
\hline
\end{tabular}

The specification of the decisions, which already received practical approbation in the world practice in the direction of transition to the "smart" city regarding perfecting of transport infrastructure of the megalopolis, are presented in the form of the most significant a case-technologies $[33,34,35,36]$ :

1) "The intellectual transport system Siemens" (the transport decision within which all the systems have direct immediate interrelation with each other). The advantages of this decision are the reducing costs of fuel, decrease in quantity of traffic jams, improvement of the transport situation.

2) "Platform technology Fujitsu" (services which allow to manage data on location, traveling speed of the vehicle are install on a paving special subsequently, then the cost characteristics of the transport network maintenance is made on the basis of the obtained analytical information calculation and also the model of traffic flow is formed).

3) "Control system of traffic by Verizon": this system provides collecting and data processing. The predicted effectiveness include reduction in time in a way of $20 \%$, reduction in fuel costs of $15 \%$, the decrease in the quantity of stops and delays of transport of $44 \%$. 
4) "Clever mobility" (case "Seoul"): wireless communication among stops and buses is created. 300 stops are supplied with wireless communication and exchange of details with 9,300 buses in which Internet modems and GPS receivers are installed.

5) Technologies of notification of drivers (cases "Singapore" and "Eindhoven").

"Singapore" system is the app for drivers, which allows to analyze data in real time and to assess the road situation.

"Eindhoven" system allows to observe humidity and smoothness of the paving; collected data are transferred to the central stations of monitoring, where "dangerous" sections of the road are defined, these data are plotted on the navigation map and the warning system of drivers works.

6) Electronic systems of payment (cases "Singapore" and "Oslo").

The systems of electronic payment in Singapore are automated completely, 34 special arches which are used for journey fixing are installed in the business center of the city. Cars of inhabitants are equipped with cache cards which are necessary for payment for driving with the possibility of replenishment of the balance by the means of them. In case of the absence of these services, the system photographs the number of a car and subsequently sends the account for the use of roads. The introduction of the systems of electronic payment considerably lowered traffic and increased the speed of receipt of money, it allows to save more than 40 million dollars on average.

The electronic system of payment also includes the collection of fees of drivers and payment at the gas stations in Oslo by the means of SMS-systems. The positive trends are the decrease in consumption of fuel and unloading of points of payment for driving.

7) Control system of the highway management (case "Gothenburg").

This system has been opened since 2004 in Sweden, and now is automated. It includes the following functions: detection of traffic jams and incidents, warning of accidents, implementation of the controlling actions. The effectiveness of application is reflected in the following: the number of incidents on the road decreased of $20 \%$, time of one trip was reduced of $5 \%$.

Such decisions can be also applied for the to megalopolises which only begin driving in the direction of "the smart city", including in St. Petersburg, where they include [31, 37]:

1. The increase in collateral operation of automobiles.

2. "Smart" traffic lights which read out and process information in real time (reduction of plug situations of $30 \%$ ), the ultrasonic sensors allowing to read out and determine the speed of traffic flow on each cloth. Application in the most loaded districts of the city is possible.

3. Promoting of cycle transport, encouragement of car owners which pass to ecologically perfect technologies.

Thus, in case of proper organization [31] of the traffic flows taking into account some features of city building planning and taking into account the ecological situation in its areas it is possible to improve the general city-planning situation in any city, thereby creating the platform for the transition to the "smart" city in the megalopolis.

\section{Conclusions}

As a rule, the transport system of megalopolises includes all or almost all types of various vehicles which have to apply innovative technologies for their further effective development and to introduce the advanced methods, allowing to be more economic, ecofriendly, social and available, to ensure safety and quality of transportations of both freights and passengers. The transport infrastructure of the city of St. Petersburg is not an exception, and it corresponds rather to the rule, as includes all the means of transport, existing now. It is rather difficult, the considerable complex of problems including ecological, connected 
generally with emissions of harmful substances in the air is formed because of great quantity of individual and city vehicles.

The research includes the characteristic of the park of the motor transport in St. Petersburg, having nearly 2 million units of vehicles. The main problems of its development are analysed and assessment of the impact on the surrounding medium is carried out. The authors offered a method of calculation, called "Green Avto Index" and also the rating of districts of the city according to the impurity of air. Calculation of Green Avto Index will allow to carry out the complex assessment of the ecological situation in the city, to analyse the trends of its change and, in subsequent, to consider the situation when planning the city building, during organization of traffic flows and within the development of the regulating measures.

Foreign experience of introduction of intellectual transport (formation of specialized pavings, the systems of the automated traffic lights, the auto-operated specialized technique, application of the modern case technologies) is presented in the article, and the possibility of the use of this experience for the domestic cities is assessed. The implementation of the concept of "clever" transport will allow to create new approaches to the use of the transport systems of megalopolises: eco-friendly cars, formation of routes with the least concentration of emissions of harmful gases, the organization of parking space, ensuring free movement of people $`$ on the territories of the city, decrease in intensity of traffic, formation of the system of monitoring, including with the use of Green Avto Index.

It is necessary to put the considerable investments into construction of the transport systems, their reconstruction and to consider their needs for further development for systematic development of infrastructure of the cities and the subsequent implementation of the "smart" city ideology. The "smart city" projects implemented now in the Russian cities, often have no complex character and come down to not the considerable modernization of separate systems. in 2017 in St. Petersburg the start is given to the city innovative program "Clever St. Petersburg" within which the concept of development of St. Petersburg by the means of technology "the smart city" is being developed, in which obligatory, desirable and perspective elements for the development of transport are presented. The mplementation of this programme will allow the transport complex of St. Petersburg to develop according to the conditions of sustainable development and world normative legal acts (such as Kyoto Protocol, Helsinki convention, etc.), to create ecologically safe habitat for the health of future generations and the modern mankind, to introduce the management of the urban environment in complex on the basis of the concept of "Smart City".

\section{References}

1. UN, 2015b. Transforming our world: the 2030 Agenda for Sustainable Development, Resolution adopted by the General Assembly, A/RES/70/1 (UN, 2015)

2. UNECE and ITU, Rome Declaration, Adopted by the participants of the Forum «Shaping smarter and more sustainable cities: striving for sustainable development goals», (2016) Access mode: https://www.itu.int/en/ITU-T/Workshops- andSeminars/Documents/Forum-on-SSC-UNECE-ITU-18-19-May-2016/RomeDeclaration-19May2016.pdf

3. Smart Cities. BSI Group [Digital resource] Access mode: https://www.bsigroup.com/en-GB/smart-cities/

4. Strategy of social-and-economic development of the Northwestern Federal District until 2020 [Digital resource] Access mode: URL: http://www.minregion.ru/pages/433?locale=ru 
5. Ltd company "Laboratory of the city development", Analytical note "The transport problems of St. Petersburg solved at the level of comprehensive planning of the territorial transport system" (2015)

6. L.M. Kapustina, Ural State University of Economicis News, 2 (64), 114-122 (2016)

7. A.S. Kopylova, A.N. Amzeev, I.T. Ivakina, Youth Scientific Forum: social-andeconomic sciences, 4 (11) (2014)

8. O.A. Dinukova, «Green» logistics in the concept of sustainable development [Digital resource] Access mode: https://docplayer.ru/70099911-Nauka-Xxi-veka-aktualnyenapravleniya-razvitiya.html

9. A.N. Voronkov, A.G. Tochkov, R.Ya. Vakulenko, Bulletin of Samara State Transport University, 2, 62-69 (2012)

10. H.Yu. Eldarhkanov, Logistics : city traffic management (Tambov, Gramota, 2008)

11. Official site of Federal public service of statistics [Digital resource] Access mode: http://www.gks.ru.

12. Report on results of work of Committee on transport for 2016 and on the plan of work for 2017 [Digital resource] Access mode: https://www.gov.spb.ru/static/writable/mediact/materials/2017/03/17/1_

13. Report "Western High-Speed Diameter. Nontechnical summary" [Digital resource] Access mode: https://bankwatch.org/documents/1_NTS_RU.pdf

14. L.A. Pepina, A.N. Sozontova, Pollution of air by automobile-and-road complex [Digital resource] Access mode: http://alfabuild.spbstu.ru/index_2017_1/8_1.pdf

15. T.R. Tereshkina, M.G. Treyman, A.A. Kopanskaya, Materials of the XXII International Bios Forum, 2, 53-57 (2017)

16. UN ECOSOC The UNECE-ITU Smart Sustainable Cities Indicators (2015) [Digital resource] Access mode: http://www.unece.org/fileadmin/DAM/hlm/documents/2015/ECE_HBP_2015_4.en.pdf

17. O.S. Varygina, Forsythe of logistics: Future of logistics by the eyes of young scientists, 156-162 (2018)

18. E. Vasilyeva, T. Sazonova, IOP Conference Series: Earth and Environmental Science, $90(1), 12116$

19. E. Vasilyeva, MATEC Web of Conferences, 170, 05005

20. V.G. Loguniva, Development of the concept of "green" logistics in the sphere of cargo transportation in Russia [Digital resource] Access mode: http://rostovlogist.ru/teoriya-logistiki/zelenaya-logistika/

21. A.V. Tereshkin, Economic-and-administrative technologies of the 21 st century: theory and practice, training of specialists: materials of the scientific-and-practical conference, 86-89 (2018)

22. M.A. Zhuravskaya, Bulletin of the Ural State University of transport and communications, 1 (25), 38-48 (2015)

23. N. Verstina, T. Tereshkina, M. Treyman, MATEC Web of Conferences, 251, 05027 (2018)

24. Tomorrow's cities: Just how smart is Songdo? [Digital resource] Access mode: http://www.bbc.com/news/technology-23757738

25. Intellectual cities. Smart cities [Digital resource] Access mode: http://www.tadviser.ru/index.php

26. A.M. Kirillov, I.I. Dmitriev, "Smart" roads and intellectual transport system [Digital resource] Access mode: http://unistroy.spbstu.ru/index_2017 53/1_dmitriev_53.pdf

27. Polyakova, E. Vasilyeva, N. Vorontsova, IOP Conference Series: Earth and Environmental Science, 90 (1), 12136 (2017) 
28. Smart decisions onthe cities development [Digital resource] Access mode: http://www.unhabitat.ru/ru/index/smartcity

29. The Green City Index. A summary of the Green City Index research series [Digital resource]

Access

mode:

//www.siemens.com/entry/cc/features/greencityindex_international/all/en/pdf/gci_repo rt_summary.pdf

30. Report "Technology of the smart cities" (St. Petersburg, 2017)

31. Smart St. Petersburg. Portal. Design office "Technology of the smart cities" (St. Petersburg [Digital resource] Access mode: https://www.petersburgsmartcity.ru/

32. UN ECOSOC (2015) The UNECE-ITU Smart Sustainable Cities Indicators [Digital resource] Access mode: http://www.unece.org/fileadmin/DAM/hlm/documents/2015/ECE_HBP_2015_4.en.pdf

33. Mapping Smart cities in the EU / Catriona Manville, Gavin Cochrane, Jonathan Cave, JUNESCO. Historic Centre of Saint Petersburg and Related Groups of Monuments [Digital resource] Access mode: http://whc.unesco.org/en/list/540

34. Smart City Expo World Congress, Topics [Digital resource] Access mode: http://www.smartcityexpo.com/en/topics

35. A.S. Kiryasov, Bulletin of Saratov state technical university, 1 (68), 299-303 (2012)

36. I.N. Omelchenko et al., Humanitarian bulletin, 10 (2013) Access mode: http://hmbul.bmstu.ru / catalog / econom / log / 118.html

37. A. Rykalin, Logistics, 11, 46-50 (2015) 